\title{
Descriptive Notes on Some Mesozoic Plants from Province Nagato (Yamaguchi Prefecture) ${ }^{*}$
}

\author{
By \\ Eitarô TAKAHASHI** \\ (Received Nov. 16, 1950)
}

\section{1) A Cone of Brachyphyllum from the Jurassic Toyora Series}

From Japan two species of Brachyphyllum were described by S. Ôishi in $1940^{1)}$; namely Brachyphyllym expansum (Sternb.) from the upper Jurassic of Province Nagato (Yamaguchi Pref.) and Brachyphyllum japonicum (Yokoyama). from the lower Cretaceous Ryôseki Series of the Outer Zone of Japan. But they are represiented only by coniferous shoots.

The materials dealt in this note were collected several years ago by T. Mizoguchi from the plant bed of the Toyora Series (or the lower part of the Kiyosue Group) of Province Nagato. They are coniferous shoots and a cone. These materials were preliminaly reported by the present author as Brachyphyllum expansum (Sternb.), ${ }^{2}$ but now they are re-examined comparing with M. W. Kendall's recent work on the cone of Brachyphyllum expansum.

In this place; the present writer's sincere thanks are due to the late $\mathrm{Mr}$. T. Mizoguchi who kindly put the specimens in my collection and to Prof. T. M. Harris of the University of Reading, England, who sent me proofs of Miss. Kendall's paper before its publication.

\section{Brachyphyllum toyoraensis, sp. nov. (Text-figs. 1--3)}

1940. Brachyphyllum expansum Oishi (non Sternb.), p. 391, P1. XXIX, figs. 10, 11, P1. XL, fig. 9.

1849. Brachyphyllum expansum Takahashi (non Sternb.), p. 40, textfig. Many sterile coniferous shoots and only one cone on black shale.

Many sterile coniferous shoots and only one cone on black shale.

Shoots: Pinnatery branched in one plane, strong in general habit. Primary branch 3-$4 \mathrm{~mm}$. thick, a secondary branch slightly thinner than the primary, about $2-3 \mathrm{~cm}$ long, straight or only slightly curved upwards, making angle of approximately $40^{\circ}-50^{\circ}$ with the primary branch. Surface of branches covered with impressions of small apressed leaves, spiraly arranged. Apex of branches somewhal rounded. Cuticle characters unknown.

Cone: Detached on the slab on which the shoots are printed. Appressed and flattned

* The writers thanks are due to the offcials of the Department of Education for their kind courtesy to grand a fund for this study.

* Institute of Geology, Faculty of Literature and Science, Yamaguchi University.

Jour, Geol. Soc. Japan, Vol. 57, No. 664, January, 1951. 


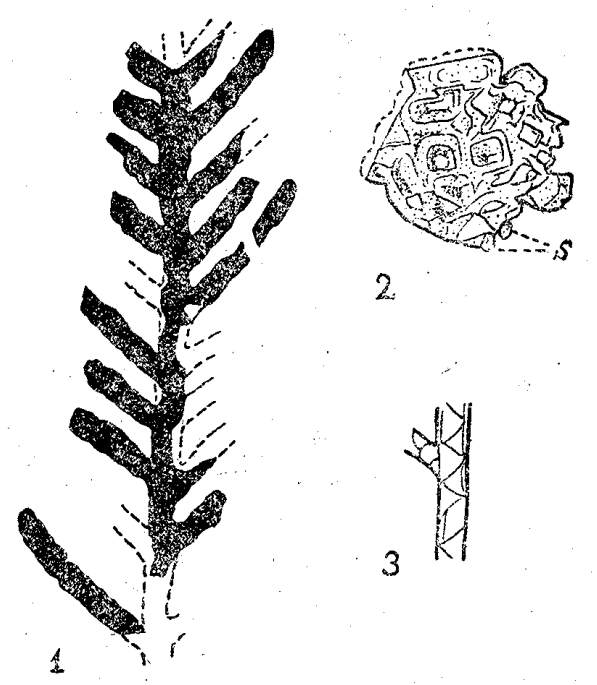

Brachyphyllum loyoraensis, sp. nov.

1. Shoot $\times 3 / 4$

2. Cast of cone $\times 3 / 4 \quad$ S...seed. Inner view.

3. Snoot $\times 3 / 4$

escutcheons. hollow cast on the shale, circular in outline, $1.5 \mathrm{~cm}$ in diameter, covered by cone scales in spiral arrangement. Number of cone scales on one plane about 15 . The cone scale, rhomboidal in outline, $0.6-1 \mathrm{~cm}$ in diameter, ornamented with escutcheons of rhomboidal or rectangular upheavals or tri-edged solid angles. Form of the inner part of cone unknown. Two small seeds, ellipsoid in outline, attached in the lowest portion of the cone.

Shoots of this species well resemble Brachyphyllum expansum (Sternb.) from the upper Jurassic of England. ${ }^{33)}$ But the habit of this cone differs from that of the English species. In $B$. expansum, the surface of cone scales are convex (see Kendall's figures), but in this new species the surface of cone scales are ornamented with

Locality: Takaji (or Takazi), Kiyosue, Toyora District, Prov. Nagato (Yamaguchi Pref.).

Geological Horizon: The Toyora Series (The Kiyosue Group), Middle -Jurassic.

\begin{abstract}
Attenda
Recently $z$ Hayashi, teacher of the Toyora Minami High-School, kindly showed me a good specimen of Brachyphyllum collected from the Toyora Series of Nanami, Toyora District. This specimen, consisting only of shoot, may possibly belong to B. toyoraensis sp. nov. It bears spirally arranged leaves over the swallen shoot (see text-fig. 3).
\end{abstract}

\title{
2) Occurrence of Plagiozamites from the Triassic Miné Series
}

Recently the writer collected Plagiozamites from the Momonoki Bed (Noric in

1) S. Ôishi: The Mesozoic Floras of Japan. (Journ. Fac. Sci, Hokkaido Imp. Univ., Ser. IV, Vol. V, Nos. 2 4, 1940)

2) E. Takahashi: Cone of Brachyphyllum expansum (Sternb.) from the Toy ora Series. (Kagaku, Vol. XIX, No. 3, 1949) (In Japanese)

3) A. O. Seward: Fossil Plants, Vol. IV, (p. 317, figs. 754-755, 1919)

4) M. W. Kendall: On Brachyphyllum expansum (Strnb.) Seward and its cone. (Ann. \& Mag. Nat. Hist., Ser. XII, 1949) (by Proof)

5) From the Toyora \& Toyonishi Series (the Kiyosue Group), 29 species of fossill plants were already described by $\mathrm{S}$. Ôishi as the lower Division of Onychiopsi Series of Yamaguchi Prefecture (see (1)). Attention should be paied to the occurrence of cone scale of Araucarites cutchensis Feist. from this area. 
age) of the Miné Series of the Ôminé Coal-fields in Province Nagato. Plagiozamites has hitherto been known from the Stephanian or Permian of the world, but not from the Triassic. The systematic position of this plant has not been settled definitely. Some authors considered it to be near Cycadophyta and the others to be near Psilophytales. ${ }^{12}$ But judging from the mode of insertation of leaves to the axis of the supposed pinnae, this plant belongs neither Cycadophyta nor Psilophytales. The leaves making two rows on each sides of axis are not spreading on one plane, nor arranging spirally. Then it is obscure that Plagiozamites represents pinnate fronds or shoot.

At any raite, it is a remarkable and noteworthy fact that the plant of Palaeozoic type was found in the Triassic of Japan. From the same locality, Neocatamites earrerei (Zeill), Dictyophyllum japonicum Yokoyama and other plants of upper Triassic were collected.

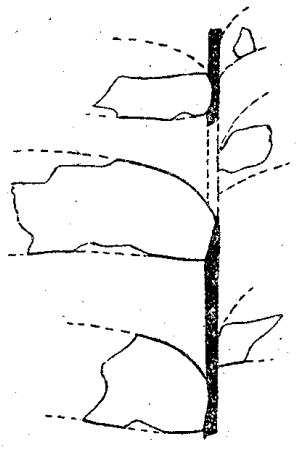

Fig. 4 Plagiozamites minensis, sp. nov.

\section{Plagiozamites minensis, sp. nov. (Text-fig. 4)}

Only one fragmental pinnate frond or shoot, more than $8 \mathrm{~cm}$ in length and more than $6 \mathrm{~cm}$ in breadth. Axis moderate, $2 \mathrm{~mm}$ broad at the base, provided with two parallel ribs. Leaves in two rows on each sides of the axis, not spread on one plane, nor arranged spiraliy, obliquely attached with rather broad and semi-amplexicaul base, forming an angle with the bedding plane, apparting $3 \mathrm{~cm}$ each other and subalternated. Leaves eblong in shape, more than $4 \mathrm{~cm}$ in length and $1.6 \mathrm{~cm}$ in breadth, almost parallel-sided, narrowing gradually toward the apical portion, and the upper margin rather abruptly contracting to the base, not petiotate, not auriculated. Apical portion of the leaves are unknown. Veins bifurcating and diverging near the base and parrallel, seldome bifurcating at several portions. Number of veins about 30 per $1 \mathrm{~cm}$.

This specimen safely belongs to Plagiozamites, though there is no comparable species. In the shape of leaves, my specimen resemble Drepanozamites nilssoni Harris of Greenland.3 But in this Greeland species the bases are Otozamites.type, My specimen also resembles Sphenozamites marioni Counillon of Annum ${ }^{3)}$ and $S$. rochei Renault of Autun.") In these species, however, the base of leaves are auriculated, but not semi-amplexicaul.

Locality: Kôda Coal Mine, Ôminé Coal-fields.

1) T. G. Halle: Palaeont. Sinica., Ser. A, Vol. II, fasc. I, p. 226, 1927.

2) T. M. Harris: Med. om Grnland., Bd. 85, Nr. 5, p. 83, pl. VII, figs. 1, 12, text-figs. 44, 45, 1932.

3) H. Counillon: Bull. serv. geol. de l'Indochine, Vol. I, fasc. 2, p. 7, pl. III, fig. 5, 5a, 1914.

4) A. C. Seward: Fossil Plants, Yol. III, p. 587, fig. 628, 1917. 


\section{3) New or Little-known Species of Podozamites from the Triassic Atsu and Miné Series}

The classification of Podozamites shoot by means of external features is very difficult as they display morphological variation. In this paper the writer deals with some new or little-known species of Podozamites collected by him from the Triassic Atsu Series (Ladino-Carnic in age) and Miné Series (Noric and Carnic in agel in Province Nagato. They are listed as follows :

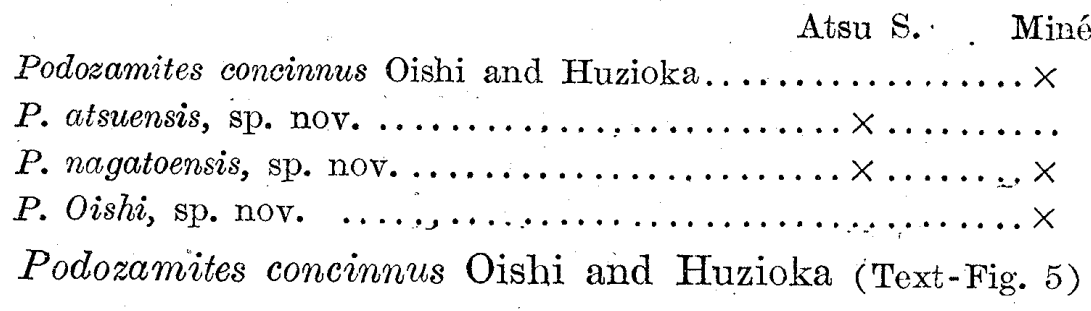

1938. Podozamites concinnus Oishi and Huzioka. Journ. Fac. Sci., Hokkaidô Imp. Univ., Ser. IV, Nos. 1-2, p. 95, pl. XII, figs. 4-7.

Somewhat larger than Nariwa specimens. Shoot small and slender, more than $9 \mathrm{~cm}$ in length. Axis very thin and delicate. Leaves probably spirally arranged around the axis, attached to the axis at an acuie angle, $4-6 \mathrm{~cm}$ in length, $6.5-7.5 \mathrm{~cm}$ in baeadth, with round apex, broadest near the proximal portion, tapiering gradually towards the base. Nerves delicate, parallel, forking near the base, converging towards the apex, numbering 16 per $6.5 \mathrm{~mm}$ or 19 per $7.5 \mathrm{~mm}$.

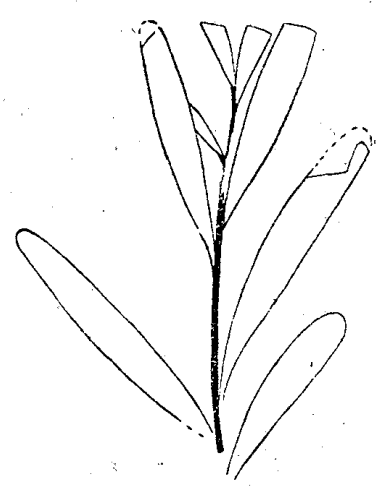

Fig. 5. P. concinnus Oishi and Huzioka

Locality: Hagiminé Coal Mine, Ômine Coal-fields.

Horizon: Momonoki Bed, Miné Series.

Podozamites atsuenisis. (Text-Fig, 6)

Detached leaves, slender and long, $8-10^{+} \mathrm{cm}$ in length, $0.7-1.1 \mathrm{~cm}$ in breadth, with rouud apex; broadest slighily below the apex, tapering gradualy towards the base and petiolated. Nerves parallel, forking near the base, converging towards the apex, numbering 11 per $0.7 \mathrm{~cm}, 12$ per $0.8 \mathrm{~cm}$ or 13 per $1.3 \mathrm{~cm}$.

The specimens somewhat resemble Podozamites concinnus Oishi and Huzioka of Nariwa, ${ }^{1)} P$. stewartensis Harris's and $P$. punctstus Harris, ${ }^{3)}$ both of Greenland. But in general habit, these three species are easily distinguishable from my specimens.

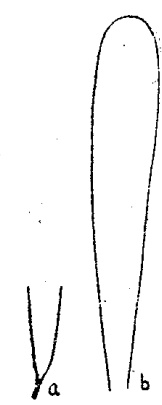

Fig. 6. Podozamites atsuensis, sp. nov.

1) S. Qishi and K. Huzioka: Op. cit., 1938. $\cdot$

2) T. M. HARRIs: Med. om Greenland, Bd. 112, Nr, 7, p. 84, pl. XIII, figs. 5, 6; pl. XVI, figs. 15, 16; text-figs. $33-34,37$ (D.E.G.), 1935.

3) T. M. Hakris: Ibid., p. 89, pl. XVIII, fig. 5; text-figs. 36, 37 (B.C.), 1935. 
Locality: Takiguchi Coal Mine, Ominé Coal-fields.

Horizon: Takiguchi Bed, Atsu Series.

Podozamitee nagatoensis sp. nov. (Text-Figs. 7-8)

1936. Podozamites sp. Oishi and Takahasbi: Journ. Fac. Sci., Hokkaido Imp. Univ., Ser. IV, Vol. III, No. 2, p. 129 , pl. X, figs. 10.

$\Lambda$ shoot and detached leaves. Shoot small in general habit. Axis very thin and delicate. Leaves probablly spirally arranged around the axis, attached to the axis at an acute angle, oblong in outline, $5 \mathrm{~cm}$ in length, 1.5- - .7 $\mathrm{cm}$ in breadth, with round apex, brodest near the proximal portion, and tapering abruply near the base. Nerves delicate, parallel, forking near the base, convering towards the appex; numbering 21 per $1.2 \mathrm{~cm}$ or 22 per $1.5 \mathrm{~cm}$.
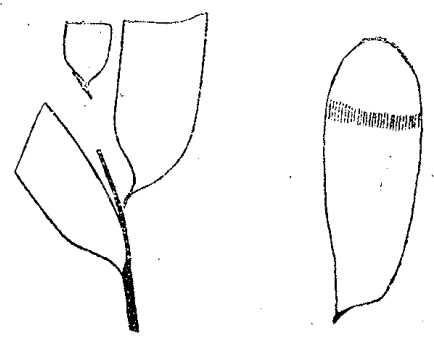

Figs, 7,8. Podozamites nagatoensis, sp nov.

The specimens strongly resemble Podozamites astartense Harris of Greenland, ${ }^{4}$ P. griesbachi Seward of Afghan and Afghan-Turkestan, ${ }^{5}$, P. griesbachi Seward of Shitaka( and Kuwashima.7) But these species do not well agree with my specimens in the shape of distal portion.

Lcoality: (1) Takiguchi Coal Miné, Ominê Coal-fièdss.

(2) Yamanoi, Asa Coal-fields.

Horizon: (1) Tagiguchi Bed, Atsu Series.

(2) Yamanoi Bed, Miné Series.

Podozamites Oishii sp. nov. (Fig. 9)

Fragmental leaves, more than $6 \mathrm{~cm}$ in length in the lower half, $2.3 \mathrm{~cm}$ in breadth, tapering rather abruptly toward the base. Nerves distinct, parallel, numbering 19 per $2.3 \mathrm{~cm}$.

This specimens resemble Cfr. Podozamites distantinervis Fontaine of Kiyosue described by Oishi. ${ }^{8 \%}$ But my specimen is more abruptly tapering than in the Kiyosue species.

Locality: Arakawa Coal Mine, Ominé Coal-fields.

Horizon: Momonoki Bed, Miné Series. .

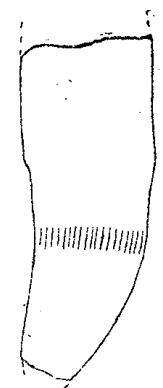

Fig. 9. Podozamites Oishii. sp. nov.

4) T. M. Harris: Op. cit., 1935, p. 87, pl. XVI, figs. 17, text-fig. 35.

5) A. C. Sry Ain: Tal. Indica, New. Ser., Vol. IV, No. 4, p. 36, pl. IV, figs. 58; p!. VI, figs. 79, 1912 .

6) S. Orshr: Journ. Tac. Sci, Hokkaido Imp. Univ, Ser. IV, Vol. Ir, No. 1, p. 12; pl. III, fig. 12.

7). S. Orshr: Ibid., Vol, V, Nos. 2-4, p. 405, 1940.

2) S. Orshi: Ibid., p. 405. pl. XLIII, figs. 4, 1940. 